\title{
Six-year fertilization modifies the biodiversity of arbuscular mycorrhizal fungi in a temperate steppe in Inner Mongolia
}

\author{
Yong-Liang Chen ${ }^{\mathrm{a}, 1}$, Xin Zhang ${ }^{\mathrm{a}, 1}$, Jia-Shu Ye ${ }^{\mathrm{a}}$, Hong-Yan Han ${ }^{\mathrm{b}}$, Shi-Qiang Wan ${ }^{\mathrm{b}}$, \\ Bao-Dong Chen ${ }^{\mathrm{a}, *}$ \\ a State Key Laboratory of Urban and Regional Ecology, Research Center for Eco-Environmental Sciences, Chinese Academy of Sciences, Beijing 100085, China \\ ${ }^{\mathrm{b}}$ College of Life Sciences, Henan University, Kaifeng, Henan 475004, China
}

\section{A R T I C L E I N F O}

\section{Article history:}

Received 6 October 2013

Received in revised form

19 November 2013

Accepted 24 November 2013

Available online 7 December 2013

\section{Keywords:}

Arbuscular mycorrhizal fungi

Abundance

Community structure

$\mathrm{N}$ fertilization

P fertilization

Temperate steppe

SSU rRNA gene

\begin{abstract}
A B S T R A C T
Arbuscular mycorrhizal fungi (AMF) play key roles in supporting ecosystem sustainability, stability and function, but little is known about how fertilization practices affect AMF abundance and community composition in the grassland ecosystems. In the present study, a field trial was established to examine the effects of 6 years of nitrogen $(N)$ and phosphorus $(P)$ fertilization on the community structure of AMF both in soils and plant roots in a typical temperate steppe in Inner Mongolia, northern China. The AMF small-subunit (SSU) rRNA genes were subjected to PCR, cloning, sequencing, and phylogenetic analyses. A total of 1554 sequenced SSU rRNA clones, including 919 clones from the soil and 635 clones from the roots, were analyzed. The 31 AMF sequence types belonging to Glomeromycota were identified: 17 to Glomus group A and 14 to Glomus group B. The experimental results indicated that $\mathrm{N}$ fertilization significantly altered the AMF communities in both soils and mixed roots but had no obvious influence on AMF abundance. However, P fertilization showed no significant influence on the AMF community structure, but induced a significant decrease in mycorrhizal colonization rate, arbuscule colonization and hyphal length density. Furthermore, $\mathrm{N}$ and $\mathrm{P}$ application showed significant interactions in affecting AMF species compositions in soils but not in roots. Generally the AMF diversity in the soil was higher than that in the roots. The study suggested that $\mathrm{N}$ fertilization predominantly altered AMF species composition, while $\mathrm{P}$ fertilization influenced AMF abundance in this steppe.
\end{abstract}

(c) 2013 Elsevier Ltd. All rights reserved.

\section{Introduction}

Arbuscular mycorrhizal fungi (AMF) belonging to the phylum Glomeromycota can form symbiotic associations with the roots of over $80 \%$ of all terrestrial plant families (Schüßler et al., 2001). They play a vital role in plant growth by providing mineral nutrients such as phosphorus $(\mathrm{P})$, nitrogen $(\mathrm{N})$, and also trace elements to their host plants (Smith and Read, 2008). Moreover, AMF can also protect their host plants from pathogen infections (Newsham et al., 1995), drought stress (Li et al., 2013) and heavy metal contaminations (Leyval et al., 1997).

It has been well demonstrated that AMF diversity can influence the biodiversity and productivity of plant communities (Van der Heijden et al., 1998). The growing evidence of the multi-function and ecological importance of AMF has triggered research interests

\footnotetext{
* Corresponding author. Tel.: +86 10 62849068; fax: +86 1062923549 . E-mail address: bdchen@rcees.ac.cn (B.-D. Chen).

1 These authors contributed equally to this work.
}

to identify their abundance and distributions in natural ecosystems. As AMF were obligate symbionts associated with host plants, the community composition of plant and AMF could be highly correlated (Oehl et al., 2003; Landis et al., 2004). However, some studies showed that highly diverse plant communities may not supported a higher AMF diversity compared with depauperate plant communities (Johnson et al., 2003a; Börstler et al., 2006), suggesting that factors other than plant diversity are also important in determining AMF communities. Distinctions between AMF communities may be partially caused by ecological specificity among fungalplant pairs (Helgason et al., 1998; Vandenkoornhuyse et al., 2003) or effects of season and host plant development stage (Husband et al., 2002a), and also possibly a result of environmental disturbance. For example, farming practices may play a key role in determining the AMF communities at both the local and regional scales (van der Gast et al., 2011).

A common agricultural practice influencing the AMF abundance and community structures is the application of fertilizers. The response of AMF communities to fertilizer addition may depend on the types, dozes and duration of fertilization. Previous studies using 
morphological (Egerton-Warburton and Allen, 2000, 2007; Bhadalung et al., 2005) and molecular identifications of AMF (Jumpponen et al., 2005; Porras-Alfaro et al., 2007; Lin et al., 2012; Liu et al., 2012) have shown that increased $\mathrm{N}$ fertilizer induced changes in AMF species richness and community structure. P fertilizer applications can also lead to changes in AMF community structures (Alguacil et al., 2010; Lin et al., 2012; Liu et al., 2012). However, most of these studies have examined the response of AMF communities to either single elements ( $\mathrm{N}$ or $\mathrm{P}$ ) or a combination of $\mathrm{N}$ and $\mathrm{P}$, but the interactive effects of the two elements have rarely been examined.

Furthermore, most studies have focused on AMF diversity either in roots (Helgason et al., 1999; Daniell et al., 2001; Vandenkoornhuyse et al., 2002a) or in soils (Alguacil et al., 2012; Lin et al., 2012), and few studies examined both simultaneously. However, the overlap between the AMF species composition in soil and the functionally active AMF communities within mycorrhizal roots has been shown to be relatively low (Clapp et al., 1995; Hempel et al., 2007). It was reported that the colonizing strategies of AMF differ considerably and this variation is taxonomically based at the family level (Hart and Reader, 2002). Therefore, a systematic investigation of AMF species composition in roots and soils is required.

In a typical steppe in Inner Mongolia, Su and Guo (2007) characterized AMF communities in non-grazed, restored and overgrazed grasslands, and Tian et al. (2009) also studied the AMF communities associated with wild forage plants. In a desert steppe, Bai et al. (2013) investigated AMF communities associated with vegetation and soil parameters under different grazing managements. However, all these studies are based on spore counts and identification of AMF by spore morphology. It has been reported that spore populations in the soil do not reflect the AMF communities in roots (Clapp et al., 1995), and spore morphological characteristics are highly imprecise as descriptions usually depend on the identifier's experience and therefore needs to be treated with caution. Recently, the application of molecular techniques to the identification of AMF in the field has revealed an unexpectedly high diversity of AMF, with many detected sequences that cannot be related to known taxa (Vandenkoornhuyse et al., 2002a). These findings have challenged the traditional knowledge of a relatively low number of AMF species. Therefore, it is equally important to characterize the AMF species using a molecular approach.

In order to examine the potential effects of nutrient addition on AMF communities, a field fertilization experiment was established in Inner Mongolia. Mycorrhizal colonization and AMF diversity in root and soil based on molecular identification were determined so as 1) to investigate the influences of different fertilization on AMF community structure both in soils and roots; 2 ) to check whether there are interactive effects of $\mathrm{N}$ and $\mathrm{P}$ fertilizers in determining the AMF abundance and species compositions.

\section{Materials and methods}

\subsection{Site description and experimental design}

This experiment was conducted in a typical temperate steppe in Duolun County (E $116^{\circ} 17^{\prime} 20^{\prime \prime}, \mathrm{N} 42^{\circ} 2^{\prime} 29^{\prime \prime}, 1324 \mathrm{~m}$ above sea level) in Inner Mongolia, China. Mean annual precipitation (MAP) is $\sim 380 \mathrm{~mm}$, with $>80 \%$ of the precipitation occurring from June to September. Mean annual temperature (MAT) in the research area is $2.1^{\circ} \mathrm{C}$, with mean monthly temperature ranging from $-17.5^{\circ} \mathrm{C}$ in January to $18.9^{\circ} \mathrm{C}$ in July. The soil on site is classified as Haplic Calcisol according to the FAO classification, or chestnut according to the Chinese classification. The native vegetation is a typical steppe community. The dominant plant species in this area are Artemisia frigida, Stipa krylovii, Cleistogenes squarrosa which are perennial herbs.

The experiment was established in 2005 with a split plot design, including four replicate plots, each containing four $44 \times 30 \mathrm{~m}^{2}$ subplots with $1 \mathrm{~m}$ wide buffer zone. The four subplots within one plot were randomly assigned to one of the four fertilizer addition treatments, including control (CK; no nutrient addition), $\mathrm{N}$ addition $\left(\mathrm{N} ; 10 \mathrm{~g} \mathrm{~N} \mathrm{~m}^{-2}\right.$ year $^{-1}$, in form of urea in 2005 and $\mathrm{NH}_{3} \mathrm{NO}_{4}$ in 2006-2011), $\mathrm{P}$ addition ( $\mathrm{P} ; 5 \mathrm{~g} \mathrm{P}_{2} \mathrm{O}_{5} \mathrm{~m}^{-2}$ year $^{-1}$, in form of calcium superphosphate), and $\mathrm{N}$ together with $\mathrm{P}$ addition (NP). Fertilizers were supplied once a year in the middle of July from 2005 to 2011.

\subsection{Sampling}

Soil samples were collected in May 2011. From each subplot, five soil cores (containing soils and roots) were randomly taken from the $0-15 \mathrm{~cm}$ topsoil and then mixed to form one composite sample. All samples were placed in a standard ice box with a temperature of $\sim 0{ }^{\circ} \mathrm{C}$ and transported to the laboratory. Soil samples were passed through a $2.0-\mathrm{mm}$ sieve, stored at $4{ }^{\circ} \mathrm{C}$ before soil chemical analysis, and at $-80^{\circ} \mathrm{C}$ before DNA extraction. At the same time, the mixed roots were handpicked from the surface of the $2.0-\mathrm{mm}$ sieve. They were washed thoroughly with distilled water. A sonicator was used to remove soil particles adhered to the root surface. Root samples were then divided into two subsamples. One was frozen at $-80^{\circ} \mathrm{C}$ for DNA extraction, and the other for monitoring mycorrhizal colonization rate and arbuscule abundance.

\subsection{Soil biological, biochemical and physical analyses}

Soil $\mathrm{pH}$ was determined at a soil to water ratio of 1: 2.5. Soil ammonium and nitrate were extracted with $2 \mathrm{M} \mathrm{KCl}$ (soil to water ratio of 1:5), and then measured with a continuous flow analyzer (SAN++, Skalar, Breda, Holland). Available soil phosphate was determined by colorimetry according to a method described by Murphy and Riley (1962). The total organic C was measured according to Yeomans and Bremner (1988). Soil total N and total carbon (C) content were measured with an element analyzer (Vario EL III, Elementar, Hanau, Germany).

Acid phosphatase and urease activities were determined according to Alguacil et al. (2010). Soil microbial biomass C was determined using a fumigation-extraction method (Vance et al., 1987). Ten grams of soil at $60 \%$ of field water holding capacity were fumigated in a $125-\mathrm{ml}$ Erlenmeyer flask with purified $\mathrm{CHCl}_{3}$ for $24 \mathrm{~h}$ placed in a glass desiccator. After removal of residual $\mathrm{CHCl}_{3}$, $40 \mathrm{ml}$ of $0.5 \mathrm{M} \mathrm{K}_{2} \mathrm{SO}_{4}$ solution was added and the sample was shaken for $1 \mathrm{~h}$ before filtration of the mixture. The $\mathrm{K}_{2} \mathrm{SO}_{4}$-extracted $\mathrm{C}$ was determined with an automatic carbon analyzer for liquid samples and microbial biomass $\mathrm{C}$ was calculated as the difference between fumigated and non-fumigated samples.

\subsection{DNA extraction and $P C R$}

A total of 32 samples, consisting of 16 soil samples and 16 root samples, were subjected to molecular analysis. Soil DNA was extracted from 0.5-g soil using the Fast DNA ${ }^{\circledR}$ SPIN Kit for Soil (Q BIOgene Inc., Carlsbad, CA, USA) according to the manufacturer's instructions. Root DNA was extracted from 100-mg fine roots using a Plant Genomic DNA Kit following protocol recommended by the manufacturer (Tiangen Biotech, Beijing, China).

The extracted DNA was diluted with double-distilled water (1: 10). Partial sequences of the SSU rRNA genes were amplified using a nested PCR with a first glomeromycotan-specific primer pair AML1 and AML2 (Lee et al., 2008), and a second primer combination of universal eukaryotic primer NS31 (Simon et al., 1992) as forward 
primer and the primer AM1 (Helgason et al., 1998) as the reverse primer. The first PCR was carried out in a final volume of $25 \mu \mathrm{l}$ with $1 \mu$ l diluted DNA template (1/10), $2.5 \mu \mathrm{l} \mathrm{10 \times PCR} \mathrm{buffer}\left(\mathrm{Mg}^{2+}\right.$ plus), $2 \mu \mathrm{l} 2.5 \mathrm{mM}$ dNTPs, $0.25 \mu \mathrm{l}$ Ex Taq polymerase $\left(5 \mathrm{U}^{-1}\right.$, Takara Biotechnology, Dalian, China), and $1 \mu \mathrm{l} 10 \mu \mathrm{M}$ of each primer. The PCR conditions were as following: $94^{\circ} \mathrm{C}$ for $5 \mathrm{~min}$, then 35 cycles of $30 \mathrm{~s}$ denaturation at $94{ }^{\circ} \mathrm{C}, 45 \mathrm{~s}$ primer annealing at $58{ }^{\circ} \mathrm{C}$ and $1 \mathrm{~min}$ extension at $72{ }^{\circ} \mathrm{C}$, followed by a final extension period of $10 \mathrm{~min}$ at $72{ }^{\circ} \mathrm{C}$. The first amplification product was diluted with doubledistilled $\mathrm{H}_{2} \mathrm{O}(1: 10)$ and $1 \mu \mathrm{l}$ of this dilution was used as a template for the second PCR amplification under the same conditions as the first PCR. All PCR products were examined on $1.5 \%(\mathrm{w} / \mathrm{v})$ agarose gels with ethidium bromide staining to confirm the product integrity.

\subsection{Cloning and sequencing}

The second PCR products were purified using the Wizard ${ }^{\circledR}$ SV Gel and PCR Clean-Up System Kit (Promega, San Luis Obispo, CA, USA), and ligated into pGEM-T Easy (Promega, Madison, WI) and then cloned into Escherichia coli cells JM109 (Takara Biotechnology, Dalian, China) according to the manufacturer's recommended protocol, resulted in a total of 32 clone libraries ( 16 clones of soil and mixed root, respectively).

Ninety putative positive transformants for each soil library and 70 putative positive transformants for each root library were picked randomly and re-amplified with the T7-SP6 primer pair. Sixty positive clones in each soil clone library and 40 positive clones in each root clone library were selected respectively for further sequencing. As a result, a total of 1600 positive clones were sequenced. All the DNA sequences were edited and compared with public databases using BLAST (Altschul et al., 1997); the nonGlomeromycotan and unqualified sequences were eliminated from the dataset, and the Glomeromycotan sequences were left for further analysis.

\subsection{Phylogenetical analysis}

All glomeromycotan sequences were aligned using DNAMAN version 6.0.3.48 (Lynnon Biosoft, USA), and clustered to species-level groups according to $97 \%$ sequence similarity. Each species-level group was regarded as an AMF phylotype. The AMF phylotypes found in this study and the GenBank sequences most similar to clone sequences in the study were included in the phylogenetic tree construction. Phylogenetic analysis was performed using MEGA version 4.0 , and the neighbor-joining tree was constructed by performing 1000 replicates to produce bootstrap values. The 31 OTU representative sequences obtained in this study had been deposited in the GenBank database with accession numbers KF916642-KF916672.

\subsection{Diversity of AM fungal community}

The Shannon-Weaver $\left(H^{\prime}\right)$ index was calculated as an additional measurement of diversity, as it combines two components of diversity, i.e., species richness and evenness. It is calculated from the equation $H^{\prime}=-\Sigma p i(\ln p i)$, where $p i$ is the number of sequences belonging to each fungal type relative to the total number of sequences.

\subsection{Assessment of AM fungal colonization, spore density and hyphal length density}

The cleaned root samples for recording mycorrhizal colonization were cut into $1 \mathrm{~cm}$-long segments. About $0.5 \mathrm{~g}$ root segments were cleared in $10 \%(\mathrm{w} / \mathrm{v}) \mathrm{KOH}$ at $90{ }^{\circ} \mathrm{C}$ in a water bath for $60 \mathrm{~min}$. After cooling, the root samples were washed and stained with $0.05 \%(\mathrm{w})$ v) Trypan blue for 30 min (McGonigle et al., 1990). Thirty root segments were mounted on slides in a polyvinyl alcohol-lactic acid-glycerol solution (Koske and Tessier, 1983) and examined at 100-400× magnification under a Nikon microscope. Intensity of the total mycorrhizal colonization (M\%) and arbuscule abundance in the root system (a\%) were estimated by the method of Trouvelot et al. (1986). This gave values for total fungal infection and arbuscular frequency. External hyphae were extracted from soil using a modified membrane filter technique and the hyphal length density (HLD) were quantified according to Jakobsen et al. (1992). A 100-g air-dried sub-sample of each soil sample was wet sieved followed by flotation centrifugation in 60\% sucrose (Dalpé, 1993) for measuring spore density.

\subsection{Statistical analysis}

Statistical analyses were performed based on SPSS version 16.0 (SPSS Inc., Chicago, IL, USA). Two-way ANOVAs were performed to examine the significance of experimental treatments and their interactions on observed parameters. Comparisons between treatments were performed using Least-Significant-Difference (LSD) test at $P<0.05$. Ordination analysis for AMF community structure was conducted using Canoco for Windows 4.5 (Ter Braak and Smilauer, 2004).

\section{Results}

\subsection{Soil chemo-physical and biological properties}

The addition of $\mathrm{N}$ fertilizer significantly decreased soil $\mathrm{pH}$ $(P<0.001$, Table 1$)$, while significantly increased soil $\mathrm{NH}_{4}^{+}$concentrations $(P<0.05)$. On the other hand, the application of $P$ fertilizers significantly decreased soil $\mathrm{NO}_{3}^{-}$concentrations $(P<0.05)$, while significantly increased soil $\mathrm{NH}_{4}^{+}(P<0.05)$ and extractable $P$ concentrations $(P<0.001)$.

The soils from the CK treatment had significantly higher phosphatase activity than soils from fertilized treatments (Table 1 ). The acid phosphatase activity was significantly decreased by both $\mathrm{N}$ $(P<0.01)$ and $\mathrm{P}(P<0.001)$ fertilization.

However, no differences in OM, TN, TC, MBC and UR were found among all treatments. Moreover, no significant interactions between $\mathrm{N}$ and $\mathrm{P}$ fertilizers were observed on these parameters (Table 1).

The total root colonization and arbuscule colonization were significantly decreased by $P$ fertilizer $(P<0.01$; Fig. 1 a,b), with the highest colonization rates in the CK plots and lowest in the NP plots. However, there were no significant interactions between $\mathrm{N}$ and $\mathrm{P}$ fertilizers on total root colonization and arbuscule colonization.

The spore density did not show significant differences among all the treatments. However, hyphal length density was significantly decreased by $\mathrm{P}$ fertilizer $(P<0.01)$. In addition, $\mathrm{N}$ and $\mathrm{P}$ fertilization interactively affected $\operatorname{HLD}(P<0.001)$, as $\mathrm{N}$ fertilization significantly increased HLD in the P-fertilized site.

\section{2. $P C R$ and rarefaction curves}

The occurrence of AMF in 16 soil samples and 16 root samples was monitored. Template DNA was successfully amplified with the first PCR primers ALM1-ALM2 and second PCR primers AM1-NS31. All second PCR produced the expected band of $550 \mathrm{bp}$, which was used for cloning and constructing clone libraries. For the 32 clone libraries, a total of 960 randomly selected positive clones for soils and 640 positive clones for roots were sequenced, respectively. After preliminary BLAST searches, a total of 1554 clones ( 919 clones for soils and 635 clones for roots) showed high similarity to 
Table 1

Soil biological and chemical properties under different fertilization treatments $(n=4)$.

\begin{tabular}{|c|c|c|c|c|c|c|c|c|c|c|}
\hline Treatments & $\mathrm{pH}\left(\mathrm{H}_{2} \mathrm{O}\right)$ & $\begin{array}{l}\mathrm{NH}_{4}^{+}-\mathrm{N} \\
\left(\mathrm{mg} \mathrm{kg}^{-1}\right)\end{array}$ & $\begin{array}{l}\mathrm{NO}_{3}^{-}-\mathrm{N} \\
\left(\mathrm{mg} \mathrm{kg}^{-1}\right)\end{array}$ & $\begin{array}{l}\text { Olsen-P } \\
\left(\mathrm{mg} \mathrm{kg}^{-1}\right)\end{array}$ & $\mathrm{OM}^{\mathrm{a}}\left(\mathrm{g} \mathrm{kg}^{-1}\right)$ & $\mathrm{TN}(\%)$ & $\mathrm{TC}(\%)$ & $\begin{array}{l}\mathrm{MBC} \\
\left(\mathrm{mg} \mathrm{kg}^{-1}\right)\end{array}$ & $\begin{array}{l}\text { Phosphatase } \\
\left(\mu \mathrm{mol} \mathrm{PNP} \mathrm{g}^{-1} \mathrm{~h}^{-1}\right)\end{array}$ & $\begin{array}{l}\text { Urease } \\
\left(\mu \mathrm{mol} \mathrm{NH} \mathrm{g}^{-1} \mathrm{~h}^{-1}\right)\end{array}$ \\
\hline $\mathrm{CK}^{\mathrm{b}}$ & $7.10 \mathrm{a}^{\mathrm{c}}$ & $5.59 \mathrm{~b}$ & $6.76 \mathrm{ab}$ & $10.50 \mathrm{c}$ & $17.18 \mathrm{a}$ & $0.20 \mathrm{a}$ & $1.97 \mathrm{a}$ & 12.61a & $11.0 \mathrm{a}$ & $10.7 \mathrm{a}$ \\
\hline $\mathrm{N}$ & $6.27 b$ & $5.96 \mathrm{~b}$ & $8.98 a$ & $8.59 \mathrm{c}$ & $17.13 a$ & $0.20 \mathrm{a}$ & $1.94 a$ & $9.82 \mathrm{a}$ & $8.9 b$ & $8.5 a$ \\
\hline $\mathrm{P}$ & $6.83 a$ & $5.89 \mathrm{~b}$ & $5.20 \mathrm{~b}$ & $37.27 \mathrm{a}$ & $19.62 a$ & $0.19 a$ & $1.82 \mathrm{a}$ & $11.47 a$ & $7.6 \mathrm{bc}$ & $9.0 a$ \\
\hline NP & $6.02 b$ & $8.36 a$ & $5.60 \mathrm{~b}$ & $30.66 b$ & $18.19 a$ & $0.18 \mathrm{a}$ & $1.73 a$ & $14.40 \mathrm{a}$ & $6.3 c$ & $7.4 a$ \\
\hline \multicolumn{11}{|c|}{ Significance of } \\
\hline $\mathrm{N}$ & $\mathbf{0 . 0 0 0} 0^{\mathrm{d}}$ & 0.022 & 0.157 & 0.053 & 0.798 & 0.723 & 0.723 & 0.983 & 0.008 & 0.092 \\
\hline $\mathrm{P}$ & 0.057 & 0.029 & 0.015 & 0.000 & 0.546 & 0.339 & 0.318 & 0.524 & 0.000 & 0.203 \\
\hline $\mathrm{N} \times \mathrm{P}$ & 0.961 & 0.077 & 0.316 & 0.258 & 0.811 & 0.82 & 0.878 & 0.295 & 0.462 & 0.778 \\
\hline
\end{tabular}

a $\mathrm{OM}$ : organic matter; TN: total nitrogen; TC: total carbon; MBC: microbial biomass $\mathrm{C}$.

b $\mathrm{CK}=$ control; $\mathrm{N}=$ fertilization with $10 \mathrm{~g} \mathrm{~N} \mathrm{~m}^{-2} \mathrm{y}^{-1} ; \mathrm{P}=$ fertilization with $5 \mathrm{~g} \mathrm{P}_{2} \mathrm{O}_{5} \mathrm{~m}^{-2} \mathrm{y}^{-1}$; NP $=$ fertilization with $10 \mathrm{~g} \mathrm{~N} \mathrm{~m} \mathrm{~m}^{-2} \mathrm{y}^{-1}$ and $_{5} \mathrm{~g} \mathrm{P}_{2} \mathrm{O}_{5} \mathrm{~m}^{-2} \mathrm{y}^{-1}$.

c Values in columns with the same letter do not differ significantly $(P<0.05)$ as determined by the least-significant-difference test.

d Significant effects $(P<0.05)$ are highlighted in bold as determined by two-way ANOVA.
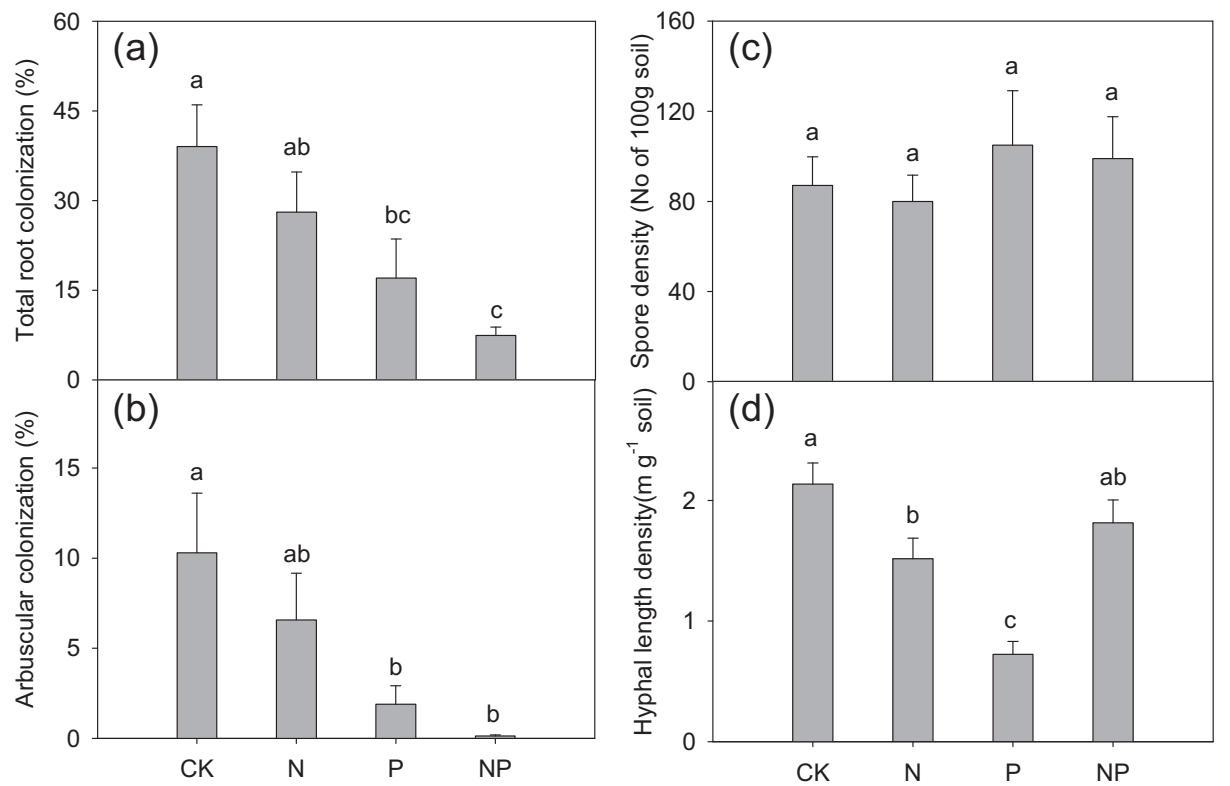

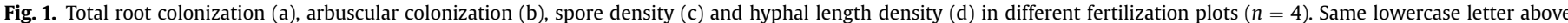

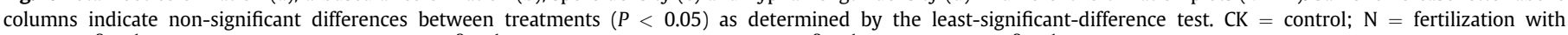
$10 \mathrm{~g} \mathrm{~N} \mathrm{~m}^{-2} \mathrm{y}^{-1} ; \mathrm{P}=$ fertilization with $5 \mathrm{~g} \mathrm{P}_{2} \mathrm{O}_{5} \mathrm{~m}^{-2} \mathrm{y}^{-1}$; $\mathrm{NP}=$ fertilization with $10 \mathrm{~g} \mathrm{~N} \mathrm{~m}^{-2} \mathrm{y}^{-1}$ and $5 \mathrm{~g} \mathrm{P}_{2} \mathrm{O}_{5} \mathrm{~m}^{-2} \mathrm{y}^{-1}$.

sequences from taxa belonging to the phylum Glomeromycota, while the remaining 46 clones were identified as non-AMF.

Sampling effort curves (Fig. 2) showed that for N and NP treatments, the number of soil and root samples analyzed was sufficient to detect the majority of AMF sequence types, since the curves reached stable plateaus. However, although the curves of CK-S and $\mathrm{P}-\mathrm{R}$ treatments showed a decreasing rate of accumulation of AMF sequence types, they did not approach saturation.

\subsection{Phylogenetic analysis of AM fungal groups}

Thirty-one AMF sequence groups in total were identified, including $30 \mathrm{AMF}$ sequence groups from soil samples and $16 \mathrm{AMF}$ sequence groups from root samples (Table 2). All the AMF phylotypes in the root samples were found in the soil samples except for DL-Glo31. All sequence groups had high similarity to AM fungi and belonged to the phylum Glomeromycota (Fig. 3). The constructed phylogenetic tree included 39 sequences which were downloaded from GenBank and 31 different AMF sequence types were recorded in this study. Seventeen of the 31 sequence groups belonged to the Glomus group A and 14 to Glomus group B. Four AMF sequence

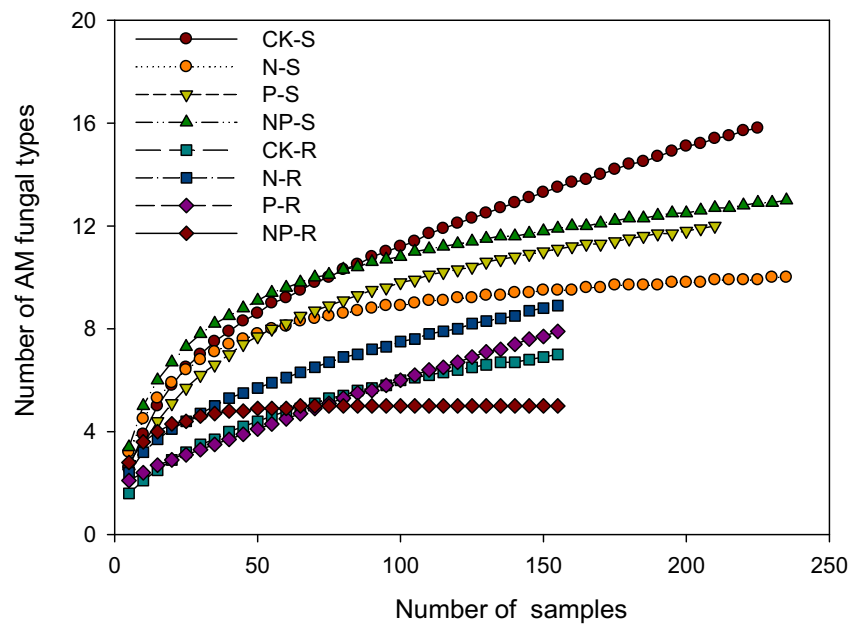

Fig. 2. Rarefaction curves for $A M$ fungal types richness. The sample order was randomized by 100 replicates in EstimateS, version 8.0 (Colwell, 2005). CK $=$ control; $\mathrm{N}=$ fertilization with $10 \mathrm{~g} \mathrm{~N} \mathrm{~m}^{-2} \mathrm{y}^{-1} ; \mathrm{P}=$ fertilization with $5 \mathrm{~g} \mathrm{P}_{2} \mathrm{O}_{5} \mathrm{~m}^{-2} \mathrm{y}^{-1}$; $\mathrm{NP}=$ fertilization with $10 \mathrm{~g} \mathrm{~N} \mathrm{~m}^{-2} \mathrm{y}^{-1}$ and $5 \mathrm{~g} \mathrm{P}_{2} \mathrm{O}_{5} \mathrm{~m}^{-2} \mathrm{y}^{-1} ; \mathrm{S}=$ soil; $\mathrm{R}=$ root. 
Table 2

Number of clones detected for each fungal type in soils and roots at the taxonomic level of $97 \%$ sequence similarity in different fertilization treatments $(n=4)$.

\begin{tabular}{|c|c|c|c|c|c|c|c|c|c|c|c|c|}
\hline & \multicolumn{4}{|l|}{ Soils } & \multicolumn{4}{|c|}{ Mixed roots } & \multicolumn{2}{|l|}{ Soils } & \multicolumn{2}{|c|}{ Mixed roots } \\
\hline & $\mathrm{CK}^{\mathrm{a}}$ & $\mathrm{N}$ & $\mathrm{P}$ & NP & CK & $\mathrm{N}$ & $\mathrm{P}$ & NP & $n$ & $\%$ & $n$ & $\%$ \\
\hline DL-Glo1 & 58 & 23 & 44 & 52 & 80 & 11 & 59 & 41 & 177 & 19.26 & 191 & 30.08 \\
\hline DL-Glo2 & 23 & 20 & 29 & 15 & 42 & 26 & 19 & 17 & 87 & 9.47 & 104 & 16.38 \\
\hline DL-Glo3 & 62 & 45 & 69 & 5 & 5 & 2 & 4 & 2 & 181 & 19.70 & 13 & 2.05 \\
\hline DL-Glo4 & 9 & 16 & 11 & 15 & 2 & 3 & 2 & 0 & 51 & 5.55 & 7 & 1.10 \\
\hline DL-Glo5 & 14 & 22 & 13 & 0 & 2 & 4 & 0 & 0 & 49 & 5.33 & 6 & 0.94 \\
\hline DL-Glo6 & 8 & 0 & 7 & 0 & 0 & 1 & 1 & 0 & 15 & 1.63 & 2 & 0.31 \\
\hline DL-Glo7 & 11 & 2 & 10 & 23 & 0 & 0 & 0 & 26 & 46 & 5.01 & 26 & 4.09 \\
\hline DL-Glo8 & 14 & 67 & 6 & 8 & 1 & 12 & 0 & 0 & 95 & 10.34 & 13 & 2.05 \\
\hline DL-Glo9 & 2 & 12 & 0 & 72 & 12 & 96 & 61 & 60 & 86 & 9.36 & 229 & 36.06 \\
\hline DL-Glo10 & 11 & 12 & 3 & 8 & 0 & 0 & 0 & 0 & 34 & 3.70 & 0 & 0.00 \\
\hline DL-Glo11 & 5 & 13 & 4 & 24 & 10 & 2 & 7 & 0 & 46 & 5.01 & 19 & 2.99 \\
\hline DL-Glo12 & 2 & 6 & 3 & 6 & 3 & 0 & 3 & 0 & 17 & 1.85 & 6 & 0.94 \\
\hline DL-Glo13 & 0 & 0 & 0 & 3 & 0 & 0 & 0 & 0 & 3 & 0.33 & 0 & 0.00 \\
\hline DL-Glo14 & 2 & 0 & 5 & 0 & 0 & 0 & 0 & 0 & 7 & 0.76 & 0 & 0.00 \\
\hline DL-Glo15 & 0 & 0 & 3 & 0 & 0 & 0 & 0 & 0 & 3 & 0.33 & 0 & 0.00 \\
\hline DL-Glo16 & 0 & 0 & 0 & 1 & 0 & 1 & 0 & 9 & 1 & 0.11 & 10 & 1.57 \\
\hline DL-Glo17 & 0 & 0 & 1 & 3 & 0 & 0 & 0 & 5 & 4 & 0.44 & 5 & 0.79 \\
\hline DL-Glo18 & 0 & 1 & 1 & 0 & 0 & 0 & 0 & 0 & 2 & 0.22 & 0 & 0.00 \\
\hline DL-Glo19 & 3 & 0 & 0 & 0 & 0 & 0 & 2 & 0 & 3 & 0.33 & 2 & 0.31 \\
\hline DL-Glo20 & 2 & 0 & 0 & 0 & 0 & 0 & 1 & 0 & 2 & 0.22 & 1 & 0.16 \\
\hline DL-Glo21 & 1 & 0 & 0 & 0 & 0 & 0 & 0 & 0 & 1 & 0.11 & 0 & 0.00 \\
\hline DL-Glo22 & 0 & 0 & 1 & 0 & 0 & 0 & 0 & 0 & 1 & 0.11 & 0 & 0.00 \\
\hline DL-Glo23 & 0 & 0 & 1 & 0 & 0 & 0 & 0 & 0 & 1 & 0.11 & 0 & 0.00 \\
\hline DL-Glo24 & 1 & 0 & 0 & 0 & 0 & 0 & 0 & 0 & 1 & 0.11 & 0 & 0.00 \\
\hline DL-Glo25 & 1 & 0 & 0 & 0 & 0 & 0 & 0 & 0 & 1 & 0.11 & 0 & 0.00 \\
\hline DL-Glo26 & 1 & 0 & 0 & 0 & 0 & 0 & 0 & 0 & 1 & 0.11 & 0 & 0.00 \\
\hline DL-Glo27 & 0 & 0 & 1 & 0 & 0 & 0 & 0 & 0 & 1 & 0.11 & 0 & 0.00 \\
\hline DL-Glo28 & 0 & 0 & 1 & 0 & 0 & 0 & 0 & 0 & 1 & 0.11 & 0 & 0.00 \\
\hline DL-Glo29 & 0 & 1 & 0 & 0 & 0 & 0 & 0 & 0 & 1 & 0.11 & 0 & 0.00 \\
\hline DL-Glo30 & 0 & 0 & 0 & 1 & 0 & 0 & 0 & 0 & 1 & 0.11 & 0 & 0.00 \\
\hline DL-Glo31 & 0 & 0 & 0 & 0 & 1 & 0 & 0 & 0 & 0 & 0.00 & 1 & 0.16 \\
\hline Total & 230 & 240 & 213 & 236 & 158 & 158 & 159 & 160 & 919 & 100 & 635 & 100 \\
\hline
\end{tabular}

${ }^{\mathrm{a}} \mathrm{CK}=$ control; $\mathrm{N}=$ fertilization with $10 \mathrm{~g} \mathrm{~N} \mathrm{~m}^{-2} \mathrm{y}^{-1} ; \mathrm{P}=$ fertilization with $5 \mathrm{~g} \mathrm{P}_{2} \mathrm{O}_{5} \mathrm{~m}^{-2} \mathrm{y}^{-1} ; \mathrm{NP}=$ fertilization with $10 \mathrm{~g} \mathrm{~N} \mathrm{~m}^{-2} \mathrm{y}^{-1}$ and $5 \mathrm{~g} \mathrm{P}_{2} \mathrm{O}_{5} \mathrm{~m}^{-2} \mathrm{y}^{-1}$.

groups were related to known AMF species that have been collected. These were DL-Glo20 for Rhizophagus intraradices, DLGlo15 for Funneliformis mosseae, DL-Glo16 for Glomus macrocarpum and DL-Glo4 for Glomus indicum. Twenty AMF sequence groups showed a high similarity to previously described sequences in GeneBank belonging to uncultured glomalean species. The remaining seven AMF sequence groups did not seem to be related to any AMF sequence in the database.

\subsection{Effects of experimental treatments on AM fungal community}

The number of AMF sequence types in soils was significantly decreased by $\mathrm{N}$ application $(P<0.01$, Fig. $4 \mathrm{a})$ ). For soils, the highest mean number of AMF phylotypes was recorded in the CK treatment, whereas the lowest was recorded in the NP treatment. For roots, the mean number of AMF phylotypes showed no significant differences among the treatments (Fig. 4b). In addition, two-way ANOVA showed that $\mathrm{N}$ fertilizer significantly decreased the Shannon diversity index of AMF community in soils $(P<0.05$; Fig. 4c) although no significant differences between treatments were confirmed by LSD test. However, no differences were found among the treatments in roots (Fig. 4d). Furthermore, the number of AMF phylotypes and Shannon diversity index in soils were higher than those in the mixed roots.

For AMF phylotypes in soils, the most abundant 5 AMF phylotypes were DL-Glo3 (19.70\% of AMF clones analyzed), DL-Glo1 (19.26\%), DL-Glo8 (10.34\%), DL-Glo2 (9.47\%) and DL-Glo9 (9.36\%), which occurred in soil samples of all four treatments, except for DL-Glo9 (Table 2). There were sequence types that seemed to occur exclusively in some specific treatments: DL-
Glo19, DL-Glo20, DL-Glo21, DL-Glo24, DL-Glo25 and DL-Glo26 in the CK controls, DL-Glo15, DL-Glo17, DL-Glo22, DL-Glo23, DLGlo27 and DL-Glo28 in the P plots, DL-Glo29 in the N plots, and DL-Glo13, DL-Glo16 and DL-Glo30 in the NP plots. Two-way ANOVA showed that $\mathrm{N}$ fertilizer had significant effect on the mean numbers of DL-Glo3 and DL-Glo9 in soils $(P<0.05$ and $P<0.05$, respectively; Fig. $5 \mathrm{~d}$, e). The mean numbers of DL-Glo9 was highest in the NP treatment, and no significant differences were found among the N, P and CK treatments (Fig. 5e). The lowest mean number of DL-Glo3 was observed in the NP treatment, whereas no differences were found between $\mathrm{CK}, \mathrm{N}$ and $\mathrm{P}$ treatments (Fig. 5d).

In roots, the most widespread 3 AMF phylotypes were DL-Glo9 (36.06\%), DL-Glo1 (30.08\%) and DL-Glo2 (16.38\%), and they occurred in the roots of all treatments (Table 2). Sequence types that occurred exclusively in some treatments were also observed in the roots. DL-Glo31 was specific to the control treatment, DLGlo16 to N plots, DL-Glo19 and DL-Glo20 to P plots, and DLGlo17 to NP plots. Furthermore, two-way ANOVA showed that the mean numbers of both root DL-Glo1 and DL-Glo11 were significantly affected by $\mathrm{N}$ fertilizer $(P<0.05$ and $P<0.05$, respectively; Fig. 5a, c), with the highest mean number in CK plots. Although neither $\mathrm{N}$ nor $\mathrm{P}$ fertilizer had significant effects on the mean numbers of root DL-Glo9, there were significant differences among the treatments, with the highest in the $\mathrm{N}$ plots and lowest in the CK plots (Fig. 5b).

The statistical analysis showed that the first two coordinates of the PCA explain $62.9 \%$ of the sequence variation (Fig. 6). The first and second principal coordinate explained $41.4 \%$ and $21.5 \%$ of the variation, respectively. The biplot diagram of PCA showed that the 


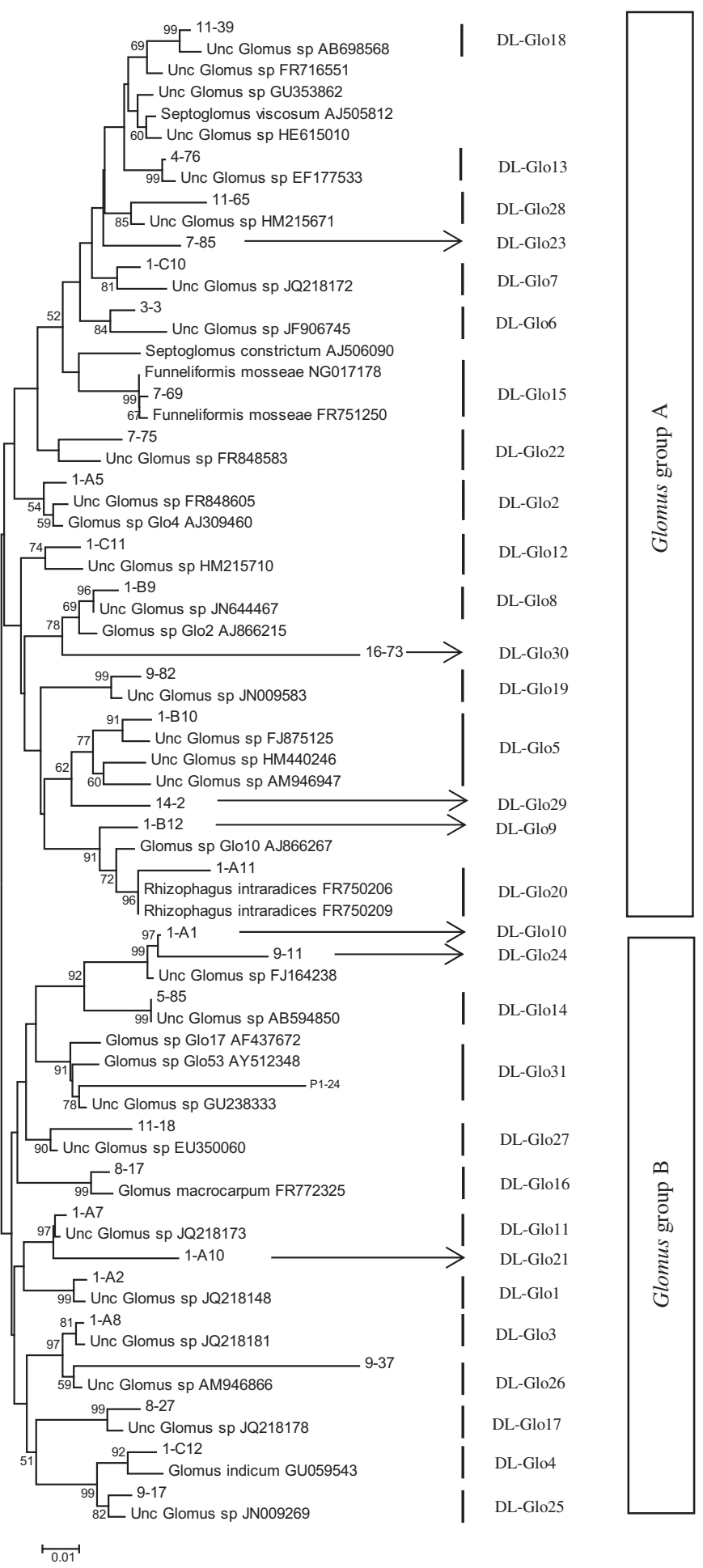

Fig. 3. Neighbour-Joining (NJ) phylogenetic tree showing examples of the AM fungal sequence types isolated from soils and roots under different fertilization treatments and reference sequences from GeneBank.

AMF communities differed significantly between soils and roots. For AMF communities in soils, the CK treatment was distant from $\mathrm{N}$ fertilization treatments ( $\mathrm{N}$ treatment and NP treatment). However, there were big overlaps of AMF species composition between $\mathrm{CK}$ treatment and $\mathrm{P}$ treatment. For the AMF communities in roots, the $\mathrm{CK}$ treatment appeared far from the $\mathrm{N}$ treatment, but close to the $\mathrm{P}$ and NP treatments.

\section{Discussions}

\subsection{AMF diversity in the temperate steppe}

To our knowledge, this study is the first to characterize AMF species composition under different fertilization practices using molecular methods in a typical temperate steppe in Inner Mongolia of northern China.

All the AMF sequences from both soils and mixed roots belonged to the family Glomeraceae, composed of 17 types in Glomus group A and 14 types in Glomus group B. We did not detect the sequences belonging to other families such as Acaulosporaceae, Diversisporaceae, Pacisporaceae and Gigasporaceae, which can potentially be detected with the primers AM1 and NS31. As expected, no sequences belonging to the families Paraglomaceae and Archaeosporaceae were detected, as the AM1 primer did not amplify sequences from these two divergent families (Redecker et al., 2000). The Glomeraceae has been shown to have the ability to colonize new roots via their mycelium or colonized root fragments (Tommerup and Abbott, 1981) and can do so at a higher sporulation rate and intensity than species from Acaulosporaceae and Gigasporaceae (Hart and Reader, 2002). Similar to present study, domination of the AMF communities by Glomus species has also been reported in forest (Husband et al., 2002a,b; Öpik et al., 2003), grassland (Vandenkoornhuyse et al., 2002a; Scheublin et al., 2004; Santos et al., 2006), wetland (Wirsel, 2004) and agricultural (Daniell et al., 2001; Hijri et al., 2006) soils.

We detected 31 different AMF phylogenetic taxa in total, suggesting a relatively high AMF diversity in this temperate steppe. These 31 AMF phylotypes, from the soils and roots, would account for around $14 \%$ of the known species, given the fact that more than 230 AMF taxa have been described so far (Krüger et al., 2012). The number of detected sequence groups revealed in this study was similar to the study of Vandenkoornhuyse et al. (2002b), who found 24 sequence groups with an intensive sampling of two host plant species in a semi-natural grassland in Scotland. However, fewer AMF phylotypes were detected in similar grassland ecosystems using the same molecular approaches. Scheublin et al. (2004) found 15 sequence types by analyzing five plant species in species-rich dune grassland in Holland. Santos et al. (2006) also found 10 discrete sequence groups by investigating two plant species in a semi-natural grassland along a fertilization gradient in Sweden. This study further suggested that the AMF in this temperate steppe exhibit a relatively high biodiversity.

\subsection{Effects of fertilization on AMF abundance and community structure}

We did not observe changes in AMF abundance in response to $\mathrm{N}$ fertilization. Similarly, Corkidi et al. (2002) and Johnson et al. (2003b) reported no significant differences in the percentage of root length colonized by AMF in $\mathrm{N}$ fertilized plants compared with control plants in semiarid grasslands. However, EgertonWarburton and Allen (2000) reported a significant reduction in spore abundance and root colonization due to $\mathrm{N}$ enrichment in southern California. This suggests that the response of AMF abundance to $\mathrm{N}$ addition is highly variable and could largely be sitedifferent caused by mean annual temperature, precipitation, edaphic conditions and host plant diversity. In the study of Van Diepen et al. (2007), of the four study sites located in sugar maple-dominated forests throughout Michigan, one site showed only a marginal decline in AMF abundance with $\mathrm{N}$ addition in July but a trend toward an increase in October, whereas other three sites showed a significant reduction in AMF colonization with $\mathrm{N}$ addition. Another possibility is that the effects of $\mathrm{N}$ enrichment on AM 

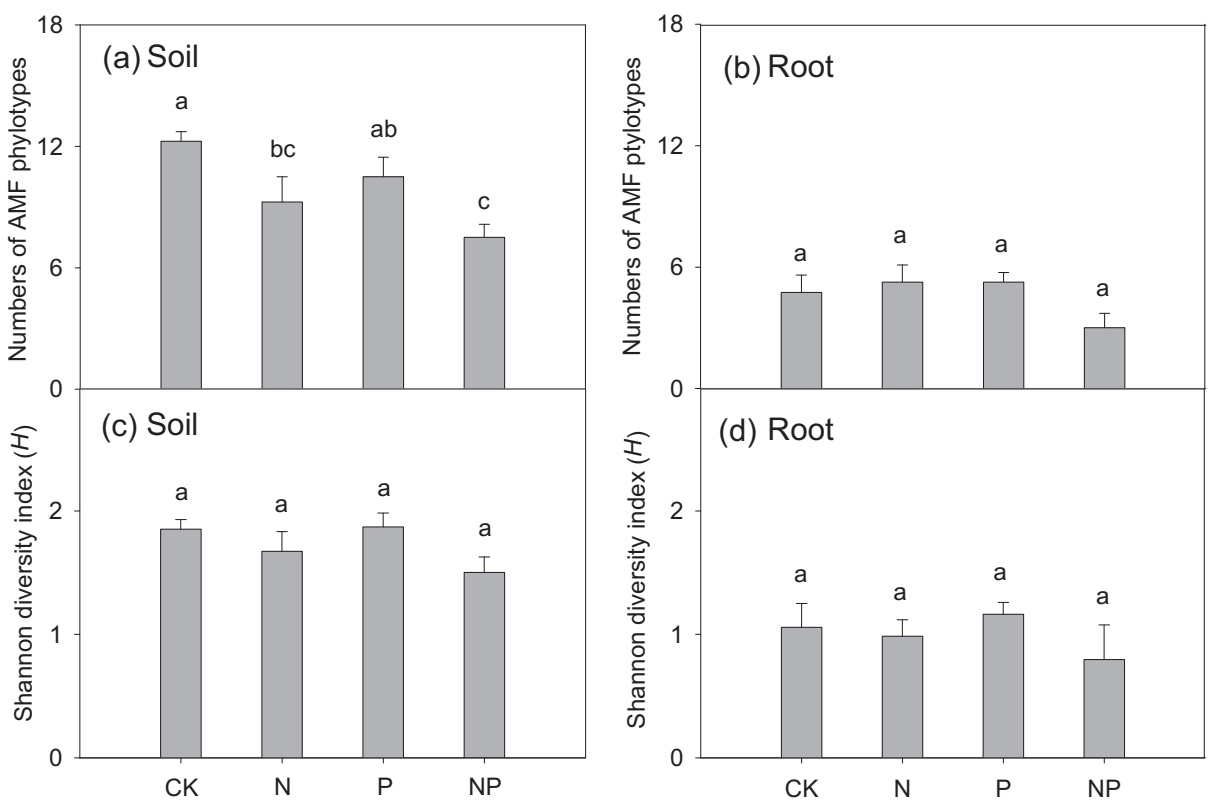

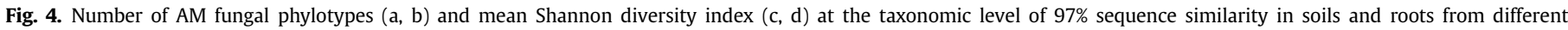

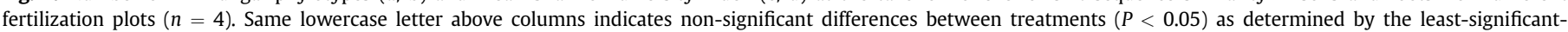

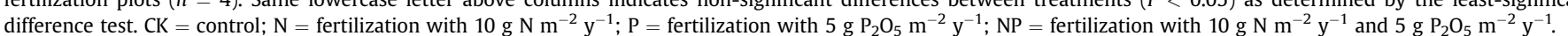

fungi have been shown to be mediated by soil P availability. $\mathrm{N}$ enrichment of $\mathrm{P}$ limited soils has been shown to increase the biomass of AM fungi while $\mathrm{N}$ enrichment of P-rich soil decreases it (Johnson et al., 2003b).

However, on the other hand, a significant reduction in soil AMF phylotypes and Shannon diversity index in response to $\mathrm{N}$ fertilization based on two-way ANOVA, and distinct changes in the composition of the AMF community between $\mathrm{N}$ treatment and $\mathrm{CK}$ treatment in both soils and roots were detected in our study. Liu et al. (2012) found a significant negative correlation between the soil available $\mathrm{N}$ and the AMF richness in mixed roots in an alpine meadow ecosystem in Tibet. Similarly, Parras-Alfaro et al. (2007) also observed a reduction of the abundance of the dominant OTU and shifts in AMF community compositions under N-amended plots in a semiarid grassland. Up to date, it is still unclear how increased amounts of $\mathrm{N}$ affect the AMF species compositions in soil or root. However, the response of AMF communities to $\mathrm{N}$ fertilization in our study may be partly related to the changes in aboveground plant communities as described in the study of Liu et al. (2012). In the same experimental field, Yang et al. (2012b) also reported that fertilization especially $\mathrm{N}$ addition significantly affected plant communities. For example, $\mathrm{N}$ addition significantly reduced community species richness by 17.5\% over the 6 years of the experiment Vandenkoornhuyse et al. (2003) confirmed that an AMF host plant preference exits, even between different grass species. Thus, changes in plant community compositions due to $\mathrm{N}$ fertilization may regulate certain preferential AMF symbionts, and subsequently alter AMF community compositions.

As expected, the AMF abundance (mycorrhizal colonization and hyphal length density) was significantly decreased by P fertilization in this study, suggesting reduced $\mathrm{C}$ allocation from host plants to AM fungi. The importance of AMF pathway in assimilating $P$ for host plants could be decreased when soil P availability is high, which is universally accompanied with a decline in AM colonization (Smith and Smith, 2011). Several evidences have proved that the extractable soil $\mathrm{P}$ concentration increases with a reduction in the percentage of root length colonized by AMF (Jensen and
Jakobsen, 1980; Ryan et al., 1994; Kahiluoto et al., 2001). However, we did not find a significant effect of P fertilization on the AMF phylotypes and species compositions. The lack of response was particularly unexpected, as large reductions in AMF abundance except for spore density had been observed in response to P fertilizer application. Dissimilar results were found in other studies that $P$ fertilization markedly modified AMF biodiversity in a tropical savanna forage system (Alguacil et al., 2010) and agricultural ecosystems (Lin et al., 2012; Gosling et al., 2013). These different observations indicate that the AMF species composition in response to $P$ additions may vary in different ecosystems. The temperate steppe that we had studied may not be firstly P-limited to some extent, and is different from the tropical forests which typically exhibit P limitation. In our study site, soil P concentration is $0.28 \mathrm{~g} \mathrm{~kg}^{-1}$ at the upper limit of the typical alpine grassland ecosystem (0.09$0.28 \mathrm{~g} \mathrm{~kg}^{-1}$, Thiel-Egenter et al., 2007). Instead, other environmental factors such as water could play a key role in limiting plant growth in this steppe (Yang et al., 2011). Furthermore, the nonsignificant changes in AMF communities in response to P fertilization may also be explained by non-significant changes in the host plant community compositions in the $\mathrm{P}$ fertilized plots compared to the $\mathrm{CK}$ plots. In our experimental plots, $\mathrm{P}$ fertilization did not significantly affect plant community species richness over the 7 years from 2005 to 2011 (Yang et al., 2012b). There was also no obvious P effects on net ecosystem $\mathrm{CO}_{2}$ exchange (NEE) (Niu et al., 2010).

Interestingly, there was a decrease in the phosphatase activity following the application of fertilizers compared to the control, but no differences were found in biomass $\mathrm{C}$ and urease activities. These parameters have been used frequently as an indicator of soil microbial activity (DeLuca and Keeney, 1993). The application of P fertilizers may suppress the phosphatase activity and consequently the AMF, since the dependence of plant community on AMF for $\mathrm{P}$ uptake could be reduced when soil available $P$ is high.

The experimental data indicated that the impact of $P$ addition on AMF community compositions in soils may also depend on soil $\mathrm{N}$ status. $\mathrm{P}$ addition significantly changed AMF community 

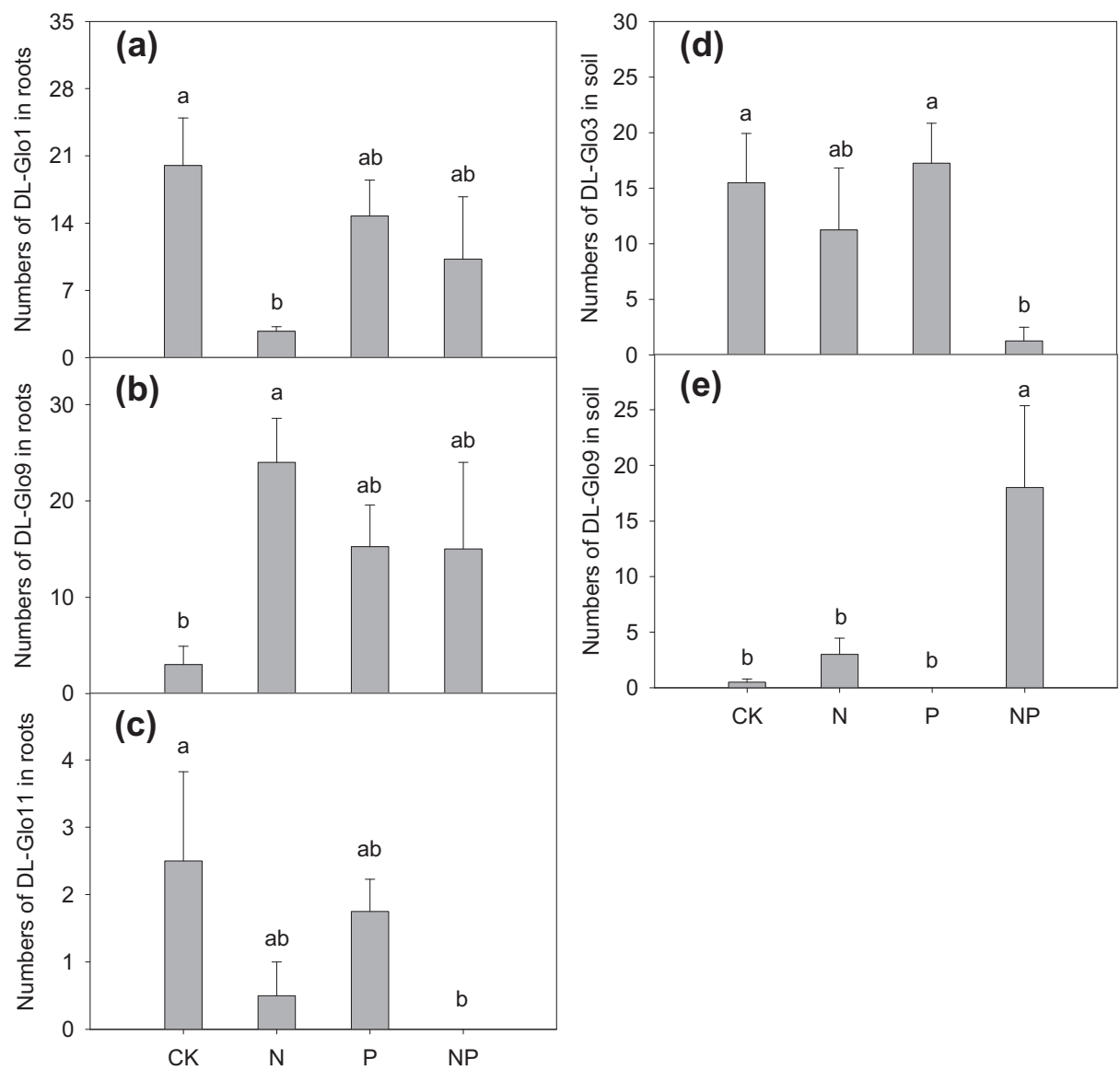

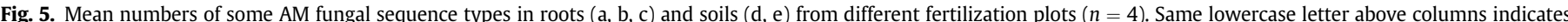

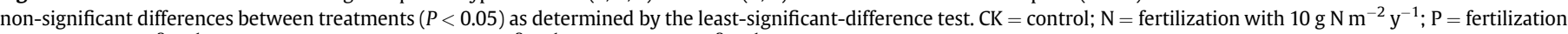
with $5 \mathrm{~g} \mathrm{P}_{2} \mathrm{O}_{5} \mathrm{~m}^{-2} \mathrm{y}^{-1} ; \mathrm{NP}=$ fertilization with $10 \mathrm{~g} \mathrm{~N} \mathrm{~m}^{-2} \mathrm{y}^{-1}$ and $5 \mathrm{~g} \mathrm{P}_{2} \mathrm{O}_{5} \mathrm{~m}^{-2} \mathrm{y}^{-1}$.

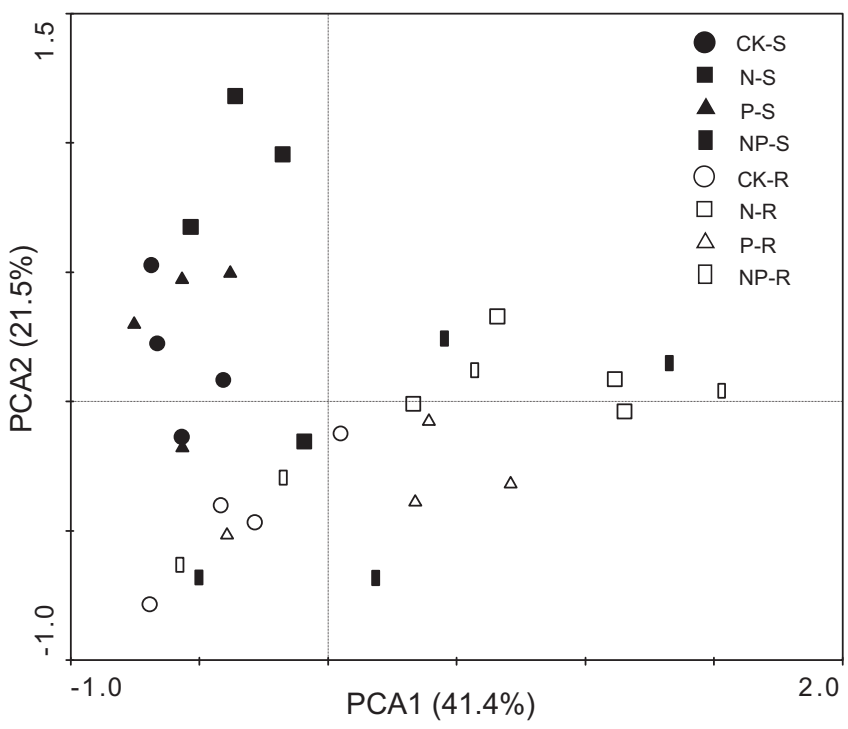

Fig. 6. Principal coordinate analysis of AM fungal communities in soils and roots in response to different fertilization treatments $(n=4) . \mathrm{CK}=$ control; $\mathrm{N}=$ fertilization with $10 \mathrm{~g} \mathrm{~N} \mathrm{~m}^{-2} \mathrm{y}^{-1} ; \mathrm{P}=$ fertilization with $5 \mathrm{~g} \mathrm{P}_{2} \mathrm{O}_{5} \mathrm{~m}^{-2} \mathrm{y}^{-1}$; $\mathrm{NP}=$ fertilization with $10 \mathrm{~g} \mathrm{~N} \mathrm{~m}^{-2} \mathrm{y}^{-1}$ and $5 \mathrm{~g} \mathrm{P}_{2} \mathrm{O}_{5} \mathrm{~m}^{-2} \mathrm{y}^{-1} ; \mathrm{S}=$ soil; $\mathrm{R}=$ root. The percentages in the axes show the percentage of variation explained by the analysis. compositions in the $\mathrm{N}$ added plots, but did not change in the non- $\mathrm{N}$ added plots, suggesting that the interaction of $\mathrm{N}$ with $\mathrm{P}$ fertilizer in shaping AMF communities in soils. Together with an observed interactive effect of $\mathrm{N}$ and $\mathrm{P}$ fertilization on hyphal length density, we hypothesized that $\mathrm{N}$ and $\mathrm{P}$ fertilizers interactively affect AMF abundance and species composition in the research area. Although the main effects of $P$ addition were not significant on AMF community compositions in soils, however, the significant effects of combined $\mathrm{N}$ and $\mathrm{P}$ fertilization suggested that $\mathrm{P}$ fertilizers could produce remarkable effects on AMF communities when supplied together with $\mathrm{N}$ fertilizers. By contrast, only combined effects of $\mathrm{N}$ and $\mathrm{P}$ fertilizers on Glomeromycota along a soil fertilization gradient was observed in the study of Liu et al. (2012) and Bhadalung et al. (2005). There is a possibility that significant P effect on AMF community compositions may be detectable in long term observations.

Of particular note was the identification of only 4 out of a total of 31 sequence groups from soils and roots matched the sequences of cultured AMF species ( $R$. intraradices, G. indicum, F. mosseae and G. macrocarpum). With regard to AMF species distribution, several studies showed that $R$. intraradices had a wide distribution in various environments (Öpik et al., 2006) and host species (Helgason et al., 2007). This species has often been related to nitrogen-enriched soils (Johnson, 1993) and considered to be a nitrophilous fungal type (Jumpponen et al., 2005). Scheublin et al. (2004) showed that $R$. intraradices was more frequent in legumes than non-legumes and concluded that this species was a strong colonizer of plants after $\mathrm{N}$ 
fertilization. However, DL-Glo20, showing high similarity (96\% identity) to $R$. intraradices, was only found in CK soils and P roots in our study. A similar result was found by Parras-Alfaro et al. (2007) that $\mathrm{N}$-amended plots showed a reduction in the abundance of this dominant OTU in a semiarid grassland. This suggests either a site-dependent response to $\mathrm{N}$, or functional diversity within this species. DL-Glo15, which can be assigned to $F$. mosseae can also be considered a generalist fungal species since it is very common in various ecosystems, including temperate arable fields (Daniell et al., 2001), tropical forests (Husband et al., 2002a,b), seminatural grasslands (Vandenkoornhuyse et al., 2002a) and wetlands (Wirsel, 2004). However, only three sequences of this species were detected in this study, suggesting that this species was exiguous in the research area.

It is interesting to note that DL-Glo4, which showed a high homology with G. indicum, was found homogeneously in both soil and root samples, suggesting an insensitivity of this AMF species to fertilization practice. This new taxon of AMF was described recently by Blaszkowski et al. (2010) in the rhizosphere of Euphorbia heterophylla L. naturally growing in coastal sands of Alappuzha in Kerala State of South India and Lactuca sativa L. cultivated in Asmara, Eritrea, North East Africa. Another culturable AMF species found in both soils and roots was DL-Glo16, which showed high similarity (99\%) with G. macrocarpum. We do not have any more information about this species, but it was shown to be exiguous in our study.

Negative response to $\mathrm{N}$ addition was also observed in several uncultured AMF taxa. As the most abundant AMF sequence types in soils, DL-Glo3 showed a negative response to $\mathrm{N}$ amendment. We also observed a negative response to $\mathrm{N}$ fertilization of DL-Glo1 and DL-Glo11, which accounted for $30 \%$ and $3 \%$ of the total 635 clones in roots, respectively. This suggested that a high $\mathrm{N}$ level was likely detrimental to the growth of these AMF species. However, DL-Glo9, the most abundant AMF sequence types in roots, accounting $36 \%$ of the total 635 sequences in roots, benefited from $\mathrm{N}$ fertilization. Moreover, this uncultured species in soils also showed a positive response to $\mathrm{N}$ addition, which suggested that this species was better at competing with other AMF taxa at higher levels of $\mathrm{N}$.

The changes in AMF community structure with $\mathrm{N}$ amendment in the present study could have implications for predicting changes in the structure and functioning of this temperate grassland ecosystem. Johnson (1993) found that fertilization may select less mutualistic AMF strains, which dominate low nutrient uptake efficiency and high carbon cost for the host plant. Similarly, Corkidi et al. (2002) also found that AM fungal communities from $\mathrm{N}$ fertilized soils were less mutualistic than those from unfertilized soils at two semiarid grasslands. In other words, these studies showed that $\mathrm{N}$ fertilization had altered the community composition and function of arbuscular mycorrhizas. Thus, the observed changes in AMF community structure have the potential to substantially change nutrient cycling in this temperate grassland. Moreover, identifying the changes in AMF species composition in response to $\mathrm{N}$ addition in this temperate steppe is a prerequisite for determining the universal rules for responses of AMF to environmental climate change such as atmospheric $\mathrm{N}$ deposition. As reported by Yang et al. (2012a), atmospheric $\mathrm{N}$ deposition in this area could be one reason for the significant decrease in soil $\mathrm{pH}$ across northern China's grasslands during 1980s-2000s. It would be of crucial importance to systematically examine the impacts of $\mathrm{N}$ deposition on the structure and function of the grassland ecosystem, including belowground components such as AMF communities.

It should be further noted that the present study on AMF communities was only a single snapshot and offered no further information on the temporal pattern of AMF community structure. This may be problematic as the AMF assemblages showed distinct seasonal dynamics in winter and summer at a study site as reported by Dumbrell et al. (2011). A seasonal and inter-annual variation in the supply of carbohydrates from host-plants, induced by changes in temperature, precipitation and sunshine hours, may serve as an important driving force for the temporal dynamics of AMF communities. Therefore, a more systematic study targeting the AMF community dynamics by observing the effects of fertilizer on AMF compositions are still expected.

\subsection{AMF communities in the soils and roots}

The large difference in AMF communities between roots and soils is another key finding in this study. Similarly, Hempel et al. (2007) found large differences in the AMF diversity between the roots and the soils at the AMF species level. However, the AMF community compositions in NP soils showed a wider distribution in the PCA plot, which might be due to the heterogeneity of the soils. At the same time, they strongly overlapped with the AMF communities in NP roots. However, the mechanism determining the overlap of AMF community between soils and mixed roots in NP plots is largely unknown.

Of the total 31 AMF sequence types, 30 and 16 were present in the soils and roots respectively, and more importantly, we also observed AMF diversity (Shannon index) was higher in soils than that in roots. Our result was in accordance with Martínez-García et al. (2011) who found higher AMF genetic diversity in soils than in roots. Differences of AMF communities in roots and soils may be due to the seasonal nature of AMF communities (Liu et al., 2009) given that AMF propagules of formerly active symbionts could remain in the soil in addition to propagules of current symbionts. Despite all, the apparent difference in AMF community structure between roots and soils proposed the necessity of more systematic investigation on AMF communities in natural ecosystem field. Consideration of both roots and soils (spores and extra-radical mycelium) may update our knowledge of the AMF biodiversity.

In summary, the present study provides convincing evidence that six years of fertilization affected AMF biodiversity in a temperate steppe in Inner Mongolia. $\mathrm{N}$ fertilizer significantly modified the AMF species composition but not AMF abundance in both soils and roots whereas $\mathrm{P}$ fertilizer addition seemed to have influence on the AMF abundance but not on the AMF community structure. In addition, we found marginal interaction of $\mathrm{N}$ with $\mathrm{P}$ fertilizer in shaping soil AMF communities. Furthermore, the soil showed higher AMF diversity than roots and harbored distinct AMF communities from those in roots except for the NP treatments, suggesting the importance of a systematic investigation on the AMF communities in both roots and soils. Further studies should focus on the ecological function of AMF in this temperate steppe. Such studies would undoubtedly lead to a better understanding of the impacts of fertilization practices and climate changes on the grassland ecosystem integrity and successions.

\section{Acknowledgements}

We would thank Andrew Smith from University of Adelaide (Australia) for revision of the manuscript. The study was financially supported by Knowledge Innovation Program of the Chinese Academy of Sciences (Project KZCX2-YW-BR-17), the National Natural Science Foundation of China (Project 41071178) and China National Funds for Distinguished Young Scientists (Project 30925009).

\section{References}

Alguacil, M.M., Lozano, Z., Campoy, M.J., Roldán, A., 2010. Phosphorus fertilisation management modifies the biodiversity of AM fungi in a tropical savanna forage system. Soil Biol. Biochem. 42, 1114-1122. 
Alguacil, M.M., Torrecillas, E., Hernández, G., Roldán, A., 2012. Changes in the diversity of soil arbuscular mycorrhizal fungi after cultivation for biofuel production in a Guantanamo (Cuba) tropical system. Plos One 7, 34887-34894.

Altschul, S.F., Thomas, L.S., Alejandro, A.S., Jingui, Z., Webb, M., David, J.L., 1997. Gapped BLAST and PSI-BLAST: a new generation of protein database search programs. Nucleic Acids Res. 25, 3389-3402.

Bai, G., Bao, Y.Y., Du, G.X., Qi, Y.L., 2013. Arbuscular mycorrhizal fungi associated with vegetation and soil parameters under rest grazing management in a desert steppe ecosystem. Mycorrhiza 23, 289-301.

Bhadalung, N.N., Suwanarit, A., Dell, B., Nopamornbodi, O., Thamchaipenet, A., Rungchuang, J., 2005. Effects of long-term NP-fertilization on abundance and diversity of arbuscular mycorrhizal fungi under a maize cropping system. Plant Soil 270, 371-382.

Błaszkowski, J., Wubet, T., Harikumar, V.S., Ryszka, P., Buscot, F., 2010. Glomus indicum, a new arbuscular mycorrhizal fungus. Botany 88, 132-143.

Börstler, B., Renker, C., Kahmen, A., Buscot, F., 2006. Species composition of arbuscular mycorrhizal fungi in two mountain meadows with differing management types and levels of biodiversity. Biol. Fertil. Soils 42, 286-298.

Clapp, J.P., Young, J.P.W., Merryweather, J.W., Fitter, A.H., 1995. Diversity of fungal symbionts in arbuscular mycorrhizae from natural community. New Phytol. 87, 259-265.

Colwell, R., 2005. EstimateS: statistical estimation of species richness and shared species from samples, version 8.0. In: User's Guide. University of Connecticut, Storrs. http://viceroy.eeb.uconn.edu/estimates.

Corkidi, L., Rowland, D.L., Johnson, N.C., Allen, E.B., 2002. Nitrogen fertilization alters the functioning of arbuscular mycorrhizas at two semiarid grasslands. Plant Soil 240, 299-310.

Dalpé, Y., 1993. Vesicular-arbuscular mycorrhiza. In: Carter, M.R. (Ed.), Soil Sampling and Methods of Analysis. Lewis Publishers, Boca Raton, pp. 287-301.

Daniell, T.J., Husband, R., Fitter, A.H., Young, J.P.W., 2001. Molecular diversity of arbuscular mycorrhizal fungi colonising arable crops. FEMS Microbiol. Ecol. 36, 203-209.

DeLuca, T.H., Keeney, D.R., 1993. Soluble anthrone-reactive carbon in soils: effect of carbon and nitrogen amendments. Soil Sci. Soc. Am. J. 57, 1296-1300.

Dumbrell, A.J., Ashton, P.D., Aziz, N., Feng, G., Nelson, M., Dytham, C., Fitter, A.H., Helgason, T., 2011. Distinct seasonal assemblages of arbuscular mycorrhizal fungi revealed by massively parallel pyrosequencing. New Phytol. 190, 794804.

Egerton-Warburton, L.M., Allen, E.B., 2000. Shifts in arbuscular mycorrhizal communities along an anthropogenic nitrogen deposition gradient. Ecol. Appl. 10, 484-496.

Egerton-Warburton, L.M., Johnson, N.C., Allen, E.B., 2007. Mycorrhizal community dynamics following nitrogen fertilization: a cross-site test in five grasslands. Ecol. Monogr. 77, 527-544.

Gosling, P., Mead, A., Proctor, M., Hammond, J.P., Bending, G.D., 2013. Contrasting arbuscular mycorrhizal communities colonizing different host plants show a similar response to a soil phosphorus concentration gradient. New Phytol. 198, $546-556$.

Hart, M.M., Reader, J.R., 2002. Taxonomic basis for variation in the colonization strategy of arbuscular mycorrhizal fungi. New Phytol. 153, 335-344.

Helgason, T., Daniell, T.J., Husband, R., Fitter, A.H., Young, J.P.W., 1998. Ploughing up the wood-wide web? Nature 394, 431.

Helgason, T., Merryweather, J.W., Young, J.P.W., Fitter, A.H., 2007. Specificity and resilience in the arbuscular mycorrhizal fungi of a natural woodland community. J. Ecol. 95, 623-630.

Hempel, S., Renker, C., Buscot, F., 2007. Differences in the species composition of arbuscular mycorrhizal fungi in spore, root and soil communities in a grassland ecosystem. Environ. Microbiol. 9, 1930-1938.

Hijri, I., Sýkorová, Z., Oehl, F., Ineichen, K., Mäder, P., Wiemken, A., Redecker, D., 2006. Communities of arbuscular mycorrhizal fungi in arable soils are not necessarily low in diversity. Mol. Ecol. 15, 2277-2289.

Husband, R., Herre, E.A., Turner, S.L., Gallery, R., Young, J.P.W., 2002a. Molecular diversity of arbuscular mycorrhizal fungi and patterns of host association over time and space in a tropical forest. Mol. Ecol. 11, 2669-2678.

Husband, R., Herre, E.A., Young, J.P.W., 2002b. Temporal variation in the arbuscular mycorrhizal communities colonizing seedlings in a tropical forest. FEMS Microbiol. Ecol. 42, 131-136.

Jakobsen, I., Abbott, L.K., Robson, A.D., 1992. External hyphae of vesicular-arbuscular mycorrhizal fungi associated with Trifolium subterraneum L. 2: hyphal transport of ${ }^{32} \mathrm{P}$ over defined distances. New Phytol. 120, 509-516.

Jensen, A., Jakobsen, I., 1980. The occurrence of vesicular-arbuscular mycorrhiza in barley and wheat grown in some Danish soils with different fertilizer treatments. Plant Soil 55, 403-414.

Johnson, D., Vandenkoornhuyse, P.J., Leake, J.R., Gilbert, L., Booth, R.E., Grime, J.P., Young, J.P.W., Read, D.J., 2003a. Plant communities affect arbuscular mycorrhizal fungal diversity and community composition in grassland microcosms. New Phytol. 161, 503-515.

Johnson, N.C., 1993. Can fertilization of soil select less mutualistic mycorrhizae? Ecol. Appl. 3, 749-757.

Johnson, N.C., Rowland, D.L., Corkidi, L., Egerton-Warburton, L.M., Allen, E.B., 2003b. Nitrogen enrichment alters mycorrhizal allocation at five mesic to semiarid grasslands. Ecology 84, 1895-1908.

Jumpponen, A., Trowbridge, J., Mandyam, K., Johnson, L., 2005. Nitrogen enrichment causes minimal changes in arbuscular mycorrhizal colonization but shifts community composition - evidence from rDNA data. Biol. Fertil. Soils 41, 217-224.
Kahiluoto, H., Ketoja, E., Vestberg, M., Saarela, I., 2001. Promotion of AM utilization through reduced P fertilization. 2. Field studies. Plant Soil 231, 65-79.

Koske, R., Tessier, B., 1983. A convenient, permanent slide mounting medium. Mycol. Soc. Am. Newslett. 34, 59.

Krüger, M., Krüger, C., Walker, C., Stockinger, H., Schüßler, A., 2012. Phylogenetic reference data for systematics and phylotaxonomy of arbuscular mycorrhiza fungi from phylum to species level. New Phytol. 193, 970-984.

Landis, F.C., Gargas, A., Givnish, T.J., 2004. Relationships among arbuscular mycorrhizal fungi, vascular plants and environmental conditions. New Phytol. 164, 493-504.

Lee, J., Lee, S., Young, J.P.W., 2008. Improved PCR primers for the detection and identification of arbuscular mycorrhizal fungi. FEMS Microbiol. Ecol. 65, 339-349.

Leyval, C., Turnau, K., Haselwandter, K., 1997. Effect of heavy metal pollution on mycorrhizal colonization and function: physiological, ecological and applied aspects. Mycorrhiza 7, 139-153.

Li, T., Hu, Y.J., Hao, Z.P. Li, H., Wang, Y.S., Chen, B.D., 2013. First cloning and characterization of two functional aquaporin genes from an arbuscular mycorrhizal fungus Glomus intraradices. New Phytol. 197, 617-630.

Lin, X.G., Feng, Y.Z., Zhang, H.Y., Chen, R.R., Wang, J.H., Zhang, J.B., Chu, H.Y., 2012 Long term balanced fertilization decreases arbuscular mycorrhizal fungal diversity in an arable soil in north china revealed by 454 pyrosequencing. Environ. Sci. Technol. 46, 5764-5771.

Liu, Y.J., He, L., An, L.Z., Helgason, T., Feng, H.Y., 2009. Arbuscular mycorrhizal dynamics in a chronosequence of Caragana korshinskii plantations. FEMS Microbiol. Ecol. 67, 81-92.

Liu, Y.J., Shi, G.X., Mao, L., Cheng, G., Jiang, S.J., Ma, X.J., An, L.Z., Du, G.Z., Johnson, N.C., Feng, H.Y., 2012. Direct and indirect influences of $8 \mathrm{yr}$ of nitrogen and phosphorus fertilization on Glomeromycota in an alpine meadow ecosystem. New Phytol. 194, 523-535.

Martínez-García, L.B., Armas, C., Miranda, J.D., Padilla, F.M., Pugnaire, F.I. 2011. Shrubs influence arbuscular mycorrhizal fungi communities in a semi-arid environment. Soil Biol. Biochem. 43, 682-689.

McGonigle, T.P., Miller, M.H., Evans, D.G., Fairchild, G.L., Swan, J.A., 1990. A new method which gives an objective measure of colonization of roots by vesicular arbuscular mycorrhizal fungi. New Phytol. 115, 495-501.

Murphy, J., Riley, J.P., 1962. A modified single solution method for determination of phosphate in natural waters. Anal. Chim. Acta 27, 31-36.

Newsham, K.K., Fitter, A.H., Watkinson, A.R., 1995. Arbuscular mycorrhiza protect an annual grass from root pathogenic fungi in the field. J. Ecol. 83, 991-1000.

Niu, S.L., Wu, M.Y., Han, Y., Xia, J.Y., Zhang, Z., Yang, H.J., Wan, S.Q., 2010. Nitrogen effects on net ecosystem carbon exchange in a temperate steppe. Glob. Change Biol. 16, 144-155.

Oehl, F., Sieverding, E., Ineichen, K., Mäder, P., Boller, T., Weimken, A., 2003. Impact of land use intensity on the diversity of arbuscular mycorrhizal fungi in agroecosystems of Central Europe. Appl. Environ. Microbiol. 69, 2816-2824.

Öpik, M., Moora, M., Liira, J., Kõljalg, U., Zobel, M., Sen, R., 2003. Divergent arbus cular mycorrhizal fungal communities colonize roots of Pulsatilla spp. in borea Scots pine forest and grassland soils. New Phytol. 160, 581-593.

Öpik, M., Moora, M., Liira, J., Zobel, M., 2006. Composition of root-colonizing arbuscular mycorrhizal fungal communities in different ecosystems around the globe. J. Ecol. 94, 778-790.

Porras-Alfaro, A., Herrera, J., Natvig, D.O., Sinsabaugh, R.L., 2007. Effect of long-term nitrogen fertilization on mycorrhizal fungi associated with a dominant grass in a semiarid grassland. Plant Soil 296, 65-75.

Redecker, D., Morton, J.B., Bruns, T.D., 2000. Ancestral lineages of arbuscular mycorrhizal fungi (Glomales). Mol. Phylogenetics Evolut. 14, 276-284.

Ryan, M.H., Chilvers, G.A., Dumaresq, D.C., 1994. Colonisation of wheat by VAmycorrhizal fungi was found to be higher on a farm managed in an organic manner than on a conventional neighbour. Plant Soil 160, 33-40.

Santos, J.C., Finlay, R.D., Tehler, A., 2006. Molecular analysis of arbuscular mycorrhizal fungi colonising a semi-natural grassland along a fertilization gradient. New Phytol. 172, 159-168.

Scheublin, T.R., Ridgway, K.P., Young, J.P.W., van der Heijden, M.G.A., 2004. Nonlegumes, legumes, and root nodules harbor different arbuscular mycorrhizal fungal communities. Appl. Environ. Microbiol. 70, 6240-6246.

Schüßler, A., Schwarzott, D., Walker, C., 2001. A new fungal phylum, the Glomeromycota: phylogeny and evolution. Mycol. Res. 105, 1413-1421.

Simon, L., Lalonde, M., Bruns, T.D., 1992. Specific amplification of $18 \mathrm{~S}$ ribosomal genes from VA endomycorrhizal fungi colonizing roots. Appl. Environ. Microbiol. 58, 291-295.

Smith, S.E., Read, D.J., 2008. Mycorrhizal Symbiosis. Academia Press, Cambridge, UK.

Smith, S.E. Smith, F.A. 2011. Roles of arbuscular mycorrhizas in plant nutrition and growth: new paradigms from cellular to ecosystem scales. Ann. Rev. Plant Biol. $62,227-250$

Su, Y.Y., Guo, L.D., 2007. Arbuscular mycorrhizal fungi in non-grazed, restored and over-grazed grassland in the Inner Mongolia steppe. Mycorrhiza 17, 689-693.

Ter Braak, C.F.J., Smilauer, P., 2004. CANOCO Reference Manual and CanoDraw for Windows User's Guide: Software for Canonical Community Ordination (Version 4.5). Biometris, Wageningen, The Netherlands.

Thiel-Egenter, C., Risch, A.C., Jurgensen, M.F., Page-Dumroese, D.S., Krüsi, B.O. Schütz, M., 2007. Response of a subalpine grassland to simulated grazing: aboveground productivity along soil phosphorus gradient. Community Ecol. 8, 111-117.

Tian, H., Gai, J.P., Zhang, J.L., Christie, P., Li, X.L., 2009. Arbuscular mycorrhizal fung associated with wild forage plants in typical steppe of eastern Inner Mongolia. Eur. J. Soil Biol. 45, 321-327. 
Tommerup, I., Abbott, L., 1981. Prolonged survival and viability of VA mycorrhizal hyphae after root death. Soil Biol. Biochem. 13, 431-433.

Trouvelot, A., Kough, J.L., Gianinazzi-Pearson, V., 1986. Mesure dutaux de mycorrhization VA d'un systeme radiculaire. Recherche de methods d'estimation ayant une signification functionnelle. In: Gianinazzi-Pearson, V., Gianinazzi, S. (Eds.), Physiological and Genetic Aspects of Mycorrhizae. INRA Paris, pp. 217-221.

Van der Heijden, M.G.A., Klironomos, J.N., Ursic, M., Moutoglis, P., StreitwolfEngel, R., Boller, T., Wiemken, A., Sanders, I.A., 1998. Mycorrhizal fungal diversity determines plant biodiversity, ecosystem variability and productivity. Nature 396, 69-72.

Van Diepen, L.T.A., Lilleskov, E.A., Pregitzer, K.S., Miller, R.M., 2007. Decline of arbuscular mycorrhizal fungi in northern hardwood forests exposed to chronic nitrogen additions. New Phytol. 176, 175-183.

van der Gast, C.J., Gosling, P., Tiwari, B., Bending, G.D., 2011. Spatial scaling of arbuscular mycorrhizal fungal diversity is affected by farming practice. Environ. Microbiol. 13, 241-249.

Vance, E.D., Brookes, P.C., Jenkinson, D., 1987. An extraction method for measuring microbial biomass carbon. Soil Biol. Biochem. 19, 703-707.

Vandenkoornhuyse, P., Baldauf, S.L., Leyval, C., Straczek, J., Young, J.P.W., 2002a. Extensive fungal diversity in plant roots. Science 295, 2051.
Vandenkoornhuyse, P., Husband, R., Daniell, T.J., Watson, I.J., Duck, J.M., Fitter, A.H. Young J.P.W. 2002b. Arbuscular mycorrhizal community composition associated with two plant species in a grassland ecosystem. Mol. Ecol. 11, 1555-1564.

Vandenkoornhuyse, P., Ridgway, K.P., Watson, I.J., Fitter, A.H., Young, J.P.W., 2003. Co-existing grass species have distinctive arbuscular mycorrhizal communities. Mol. Ecol. 12, 3085-3095.

Wirsel, S.G.R., 2004. Homogenous stands of a wetland grass harbour diverse consortia of arbuscular mycorrhizal fungi. FEMS Microbiol. Ecol. 48, 129-138.

Yang, H.J., Jiang, L., Li, L.H., Li, A., Wu, M.Y., Wan, S.Q., 2012b. Diversity-dependent stability under mowing and nutrient addition: evidence from a 7-year grassland experiment. Ecol. Lett. 15, 619-626.

Yang, H.J., Li, Y., Wu, M.Y., Zhang, Z., Li, L.H., Wan, S.Q., 2011. Plant community responses to nitrogen addition and increased precipitation: the importance of water availability and species traits. Glob. Change Biol. 17, 2936-2944.

Yang, Y.H. Ji, C.J., Ma, W.H., Wang, S.F., Wang, S.P., Han, W.X., Mohammatk, A. Robinson, D., Smith, P., 2012a. Significant soil acidification across northern China's grasslands during 1980s-2000s. Glob. Change Biol. 18, 22922300.

Yeomans, J.C., Bremner, J.M., 1988. A rapid and precise method for routine determination of organic carbon in soil. Commun. Soil Sci. Plant Anal. 19, 1467-1476. 